\title{
Development of Current Stick Teaching Aids to Improve Students' Generic Science Skills
}

\author{
Nur Khoiri ${ }^{1}$, Choirul Huda ${ }^{2}$, Joko Saefan ${ }^{3}$, Wawan Kurniawan ${ }^{4}$ \\ Universitas PGRI Semarang, Indonesia ${ }^{1,2,3,4}$ \\ nurkhoiri78@gmail.com¹, choirulhuda581@gmail.com², jokosaefan@gmail.com³, \\ wawan.hitam@gmail.com ${ }^{4}$
}

Received: August $27^{\text {th }}, 2020$. Revised: September $21^{\text {st }}, 2020$. Accepted: September $28^{\text {th }}, 2020$

\section{Keywords :}

Development; Generic Science

Skills; Current Stick

\begin{abstract}
The study aimed to develop the Current Stick teaching aids and determine its effectiveness to improve students' generic skills. The type of research is development research which involved 180 students of class X SMAN in Blora were chosen through cluster random sampling. The instrument used to collect the data was a validated question sheet from the assessment of students' practicum report in using Current Stick teaching aids and the observation sheet. The instruments were addressed to students from the control class and experimental class. The obtained data were tabulated and analyzed by using $t$-test. The result shows that the experimental class achieved an average percentage of generic science skills of $77.2 \%$, while the control class reached $66.4 \%$. It reveals that the difference in the percentage of generic science skills is the result of using Current Stick teaching aids. Based on the results and discussion, it was found that the development of Current Stick teaching aid is effective to improve students' Generic Science skills.
\end{abstract}

\section{INTRODUCTION}

The life challenges in the 21st century require young generations to master variety of relevant skills. Therefore, one of the expectations for the education field is that prepare future generations to master these various skills in order to emerge as an adaptive and successful generation in facing life's challenges [1] [2] [3]. Align to the need of preparing the generations with the various skills, the generic science skills could contribute to provide them an opportunity which is more beneficial for students in their daily life. Generic science skills were divided into cognitive skills which specifically related to scientific thinking and an affective skill. The types of skills that really need to be trained in the learning process are critical thinking skills, metacognition, communication skills, problem solving, collaboration, creation and innovation, technology and information literacy [4] [5] [6] [7]. The achievement of these skills are done by updating the learning paradigm and the quality of the learning process. Moreover, renewing the learning paradigm is marked by developing student participation, adjusting the characteristics of learning methods, project/problem-based learning, communication, cooperation, 
participation and student motivation. Learning is designed in accordance with the real world, by developing student-centered learning and empowering metacognition [8] [9] [10] [11].

Since the importance of the learning process which is connected to the real word, the generic science skill could provide the students with the cognitive and affective skill that is beneficial for their daily life after learning science. Therefore, the science learning process has a very strategic role in shaping the character of students in the development of science and technology, as well as ways of thinking that are relevant to daily needs [12] [13]. Although currently, the contribution of science in technology aspect is experiencing very rapid development and able to make life better, until now science learning has not been taught properly. However, the teaching process still does not meet the criteria of mastering the content knowledge, therefore, the learning outcomes in science today are still lower compared to other subjects. It is suspected that this condition occurs because science is still considered a subject that does not provide opportunities for students to develop useful skills in everyday life, such as generic science skills and problem solving skills, does not interesting subject and difficult to understand [14] [15] [16] [17]. Moreover, mastering a few indicators of generic science skills help students to master many science concepts [18]. Therefore, science teaching quality could be improved from science concepts which is comprehension to thinking through science.

Generic science skills in the science learning process can be grouped into 9 aspects, namely direct observation, awareness of scale, indirect observation, symbolic language, logical framework based on natural laws, logical inference, causal law, mathematical modeling, and concept building [18]. Generic thinking skills can be developed through more active physics learning [19] [20]. Based on the analysis of the results of national examinations, it can be stated that generic science skills or issues for mathematical modeling skills, and the logical consistency of the aspects of generic science skills are still not adequately trained [21] [22]. From these results, researchers intend to re-analyze the generic skills of science.

Virtual Laboratory Learning shows that the highest impro6'vement is the aspect of generic science skills in logic inference and the ability to build concepts [23] [24]. From the differences made in previous studies, the researchers chose to re-conduct research on aspects of generic science skills. In line with the observations made in SMA in Blora district, the teacher explained that in addition to the actions taken by the teacher and the school, there are several factors that affect students' generic science skills.Factors that affect the generic science skills of high school students in Blora are the lack of student interest in learning, environmental conditions, and conventional teacher policies. Other issue that affects students' generic science skills is the lack of facilities and infrastructure that support the learning process. Physics learning really requires complete facilities and infrastructure to fulfill the practicum process [25] [26]. The teacher reveals that physics is difficult for students to understand. Therefore, the present study makes the efforts to develop Current Stick teaching aids to improve students' generic science skills on dynamic electricity material.

\section{METHOD}

The study involves a development research in producing the teaching aids of Current Stick in topic dynamic electricity. The development research was conducted to test how effective the product to improve the students' generic science skills during research activities [27] [28]. The procedure of development research in the scope of education begins with the validation stage of the products produced during the research process. The stages in research are also referred to as cyclical process that begins with findings of research relevant to the product to be developed, compiles, tests and revises them to correct deficiencies found in the testing phase. This cycle is repeated until the product meets the defined objectives. Meanwhile, to determine how effective the developed product to improve the students' generic science, the researcher involves 180 students of class X SMAN in Blora that have been chosen by using cluster random sampling for occupying the control class and experimental class. 
Research instrument was used as a tool to collect research data [27] [29]. The instruments used in the research implementation process are the observation sheet instruments and the assessment of practicum report instruments. The observation sheet instrument was used in the form of statements or criteria to assess students' generic science skills through practical activities particularly to assess the affective skill. Meanwhile the assessments of practicum report instruments was used to assess the students' generic science skills particularly related to the cognitive skills. The analysis of implementation program was carried out by using qualitative and quantitative descriptive analyzes. The learning implementation score is based on observations made by two people. The observers gave an assessment with a sign $(\sqrt{ })$ in the column provided with the criteria for score of 4 (Very Good), score of 3 (Good), score of 2 (Poor), and score of $1(\mathrm{Bad})$. The assessment criteria are obtained from the average rating scale given by the two observers with the assessment criteria as in Table 1.

Table 1. Program Implementation Assessment Criteria [29]

\begin{tabular}{cc}
\hline Score Range & Criteria \\
\hline $3,25 \leq \mathrm{P}<4,00$ & Very Good \\
$2,50 \leq \mathrm{P}<3,25$ & Good \\
$1,75 \leq \mathrm{P}<2,50$ & Poor \\
$1,00 \leq \mathrm{P}<1,75$ & Bad \\
\hline
\end{tabular}

Data analysis from the relevant student responses questionnaire used descriptive quantitative and qualitative. Program development is considered successful if it meets the criteria of good or very good. Furthermore, the number of students who scored good and very good is added up and a percentage is made to describe the students who are affected by the program being developed.

\section{RESULTS AND DISCUSSIONS}

The research process begins with validating the physics teaching aids carried out by high school teachers. The validation activities are intended to obtain a valid physics teaching aids and are able to produce appropriate practicum data. The validation process is carried out in two stages, the validation results are applied to product revisions. The stage I was carried out by class $\mathrm{X}$ teachers which obtaining an eligibility percentage of $78 \%$ in the good category. This means that the teaching aids are declared valid and suitable for implementing in the classroom. There are 2 suggestions from phase I validation process, namely the neatness of the appearance of the tools and clarity of use or information on tool use. Furthermore, phase 2 validation process is carried out, and the results obtained were $87 \%$ in the good category. There is one suggestion from the results of phase 2 validation process, namely the description of the teaching aids variables. Furthermore, improvements are made based on notes from the validator, until a program that is valid and suitable for use is obtained. This means that the physics teaching aids developed can be categorized as high quality products because they have valid criteria [30]. The next stage is testing the current stick teaching aids to see the impact on generic science skills after going through learning process using the developed tools. The research conducted involved control class and the experimental class. The experimental class used the teaching aids along with the guidance devices developed, while the control class used learning model with practicum tools already available in laboratory.

The learning outcomes of the control class can be observed from each aspect of Generic Science skills. The score is calculated to get the very good and good category. Furthermore, the good and very good categories are added up as a percentage. For all aspects of generic science skills, the mean percentage for experimental class was higher than control class. The average achievement of the experimental class after good and very good categories adding up for was $77.2 \%$, while for the control class the average achievement was $66.4 \%$. By using the t-test data analysis, it was obtained the t-hitung $=1.992898$ and the $\mathrm{t}$-table $=1.667$, with the significance degree $5 \%$ means that h0 is rejected and $\mathrm{Ha}$ is accepted. Moreover, this percentage achievement illustrates that the developed Current Stick teaching aids have significant impact on students' generic science skills. Furthermore, based on the observations made 
during the research process, the impact of changes in generic science skills is the result of changes in student participation and activity during the learning process. The developed teaching aids and guides have created a practicum atmosphere that stimulates student participation. A fun learning process will be able to develop the expected skills during the learning process [31] [32].

Aspects of generic science skills can be grouped into activity groups (affective motoric) and cognitive [33] for activity-related skills. There is only a slight difference between the skill achievement between the control class and the experimental class. The explanation for this condition is presumably because the activities for the control class and the experimental class are relatively the same for the type of practicum activity. Students are very accustomed to doing practicum activities so that the skills in these aspects are on average good and very good. Students who are accustomed to practicum activities will have better motoric skills [34] [35] [36]. Activities in the context of this research include direct and indirect observation, symbolic language, and scale awareness. In more detail, each aspect can be seen in Table 2.

Table 2. Generic Science Skill Achievement

\begin{tabular}{cccc}
\hline No & Aspect & Experiment Class & Control Class \\
\hline 1 & Direct observation & $82 \%$ & $80 \%$ \\
2 & Indirect observation & $80 \%$ & $78 \%$ \\
3 & Awareness of scale & $80 \%$ & $76 \%$ \\
4 & Symbolic language & $73 \%$ & $79 \%$ \\
5 & Logic framework & $76 \%$ & $65 \%$ \\
6 & Cause and effect & $78 \%$ & $65 \%$ \\
7 & Logic inference & $75 \%$ & $50 \%$ \\
8 & Mathematical modeling & $76 \%$ & $55 \%$ \\
9 & Concept building & $75 \%$ & $50 \%$ \\
\hline \multicolumn{4}{c}{ Average } \\
\hline
\end{tabular}

The percentage of achievement difference in cognitive aspects of generic science skills is quite large. It is suspected that the significant difference is caused by the design of practicum activities using different current stick teaching aids, so that it has an impact on students' skills in explaining the data from practicum activities logically. Activities in the experiment class have been designed for the aspect of generic science skills, so the activity guide is different from practicum guide as it has been in the teaching aid kit. Activity guides need to be designed according to the objectives of the expected learning process [37] [38]. Aspects of logic framework, cause and effect, logic inference, mathematical modeling and concept building are series of activities carried out as a follow-up to the results of the practicum carried out. The developed teaching aids have become a trigger for increasing students' activity and participation in the physics learning process. The active participation of students in the learning process has an impact on increasing students' generic science skills. Similar activities did not appear in the control class, so it is strongly suspected that the development of currenstick teaching aids has a significant impact on generic science skills.

\section{CONCLUSION AND SUGGESTION}

Based on the findings, it can be concluded that the Current Stick teaching aids and its guidance are valid and suitable for implementing in the classroom. This product has been tested in the population through the experimental and control class which show that the product is effective to improve the students' generic science skill. It is shown from the experimental class that achieved an average percentage of generic science skills of $77.2 \%$, while the control class reached $66.4 \%$. However, for the further research it is important to conduct the research into wider population to disseminate the product. 


\section{REFERENCES}

[1] Trilling, B. \& Charles, F. (2009). $21^{\text {st }}$ Century Skill. San Fransisco: Joosey-Bass A Wiley Imprint.

[2] Mc Pherson-Geyser, G., de Villiers, R., \& Kavai, P. (2020). The Use of Experiential Learning as a Teaching Strategy in Life Sciences. International Journal of Instruction, 13(3): 877-894.

[3] Wong, G. K. W., \& Cheung, H. Y. (2020). Exploring children's perceptions of developing twentyfirst century skills through computational thinking and programming. Interactive Learning Environments, 28(4): 438-450.

[4] Wahyuni, I., \& Amdani, K. (2016). Influence Based Learning Program Scientific Learning Approach to Science Students Generic Skills. Journal of Education and Practice, 7(32): 104-108.

[5] Brachem, J. C., \& Braun, E. M. (2018). Job-related requirements and competences of educational science graduates. Journal of further and higher education, 42(2): 166-176.

[6] Herranen, J., \& Aksela, M. (2019). Student-question-based inquiry in science education. Studies in Science Education, 55(1): 1-36.

[7] Yu, K. C., Wu, P. H., \& Fan, S. C. (2019). Structural relationships among high school students' scientific knowledge, critical thinking, engineering design process, and design product. International Journal of Science and Mathematics Education, 18(6): 1-22.

[8] Zubaidah, S. (2016, December). Keterampilan abad ke-21: Keterampilan yang diajarkan melalui pembelajaran. In Seminar Nasional Pendidikan dengan Tema "isu-isu strategis pembelajaran MIPA Abad (Vol. 21, No. 10).

[9] Szostkowski, A., \& Upadhyay, B. (2019). Looking forward by looking back: equity in science education as socially just and morally healing action. Cultural Studies of Science Education, 14(2): 335-353.

[10] Akben, N. (2020). Effects of the problem-posing approach on students' problem solving skills and metacognitive awareness in science education. Research in Science Education, 50(3): 1143-1165.

[11] García-Carmona, A. (2020). From Inquiry-Based Science Education to the Approach Based on Scientific Practices: A Critical Analysis and Suggestions for Science Teaching. Science \& Education, 29(2): 443-463.

[12] Bogar, Y. (2019). Synthesis Study on Argumentation in Science Education. International Education Studies, 12(9): 1-14.

[13] Ünlü, Z. K., \& Dökme, İ. (2020). The Effect of Technology-Supported Inquiry-Based Learning in Science Education: Action Research. Journal of Education in Science Environment and Health, 6(2): 120-133.

[14] Gök, T., \& Silay, I. (2008). Effects of Problem-Solving Strategies Teaching on the ProblemSolving Attitudes of Cooperative Learning Groups in Physics Education. Journal of Theory \& Practice in Education (JTPE), 4(2).

[15] Aragoneses, A., Salán Ballesteros, M. N., \& Hernández Fernández, A. (2017). Disclosure Day on Relativity: A Science Activity Beyond the Classroom. World journal on educational technology, 9(2): 59-66.

[16] Reiss, M. J. (2018). Beyond 2020: ten questions for science education. School Science Review, 100(370): 47-52.

[17] Pratono, A., Sumarti, S. S., \& Wijayati, N. (2018). Contribution of assisted inquiry model of emodule to students science process skill. Journal of Innovative Science Education, 7(1): 62-68.

[18] Liliasari, L. (2007). Pembelajaran Sains untuk Membangun Insan Indonesia Cerdas dan Kompetitif. Laporan HPTP. Sekolah Pascasarjana: Universitas Pendidikan Indonesia.

[19] Sudarmin, S., Sumarni, W., Zahro, L., Diba, P. F., \& Rosita, A. (2018). The Development of Learning Chemistry Module Integrated with Green Chemistry and Ethnoscience to Development of Students' Generic Science Skills and Soft Skills of Conservation in Central Java. Journal of 
Science and Mathematics Education in Southeast Asia, 41.

[20] Brotosiswoyo, S. (2001). Hakikat Pembelajaran MIPA di Perguruan Tinggi. Jakarta: Universitas Terbuka PAU-PPAI-UT.

[21] Fatmayanti, S. D., \& Sarwanto, S. (2017). Science Generic Skills Improvement Through Student Centerd Learning. Journal ICIE, 1(1).

[22] Jääskelä, P., Nykänen, S., \& Tynjälä, P. (2018). Models for the development of generic skills in Finnish higher education. Journal of Further and Higher Education, 42(1): 130-142.

[23] Gunawan, G., Setiawan, A., \& Widyantoro, D. H. (2014). Model virtual laboratory fisika modern untuk meningkatkan keterampilan generik sains calon guru. Jurnal Pendidikan dan Pembelajaran (JPP), 20(1): 25-32.

[24] de Vries, L. E., \& May, M. (2019). Virtual laboratory simulation in the education of laboratory technicians-motivation and study intensity. Biochemistry and Molecular Biology Education, 47(3): 257-262.

[25] Khoiri, N., \& Hindarto, N. (2011). Pengembangan perangkat pembelajaran fisika berbasis life skill untuk meningkatkan minat kewirausahaan siswa. Jurnal Pendidikan Fisika Indonesia, 7(2).

[26] Hermansyah, H., Gunawan, G., \& Harjono, A. (2017). Pengaruh Penggunaan Laboratoium Virtual Dalam Pembelajaran Inkuiri Terbimbing Terhadap Penguasaan Konsep Kalor Peserta Didik. Jurnal Pendidikan Fisika dan Teknologi, 3(2): 249-256.

[27] Sugiyono. (2015). Metode Penelitian Kuantitatif Kualitatif dan R\&D. Bandung: Alfabeta.

[28] Creswell, J. W. (2016). Research Design Pendekatan Kualitatif, Kuantitatif, dan Mixed. Yogyakarta: Pustaka Pelajar.

[29] Rüschenpöhler, L., \& Markic, S. (2019). Self-concept research in science and technology education-theoretical foundation, measurement instruments, and main findings. Studies in Science Education, 55(1): 37-68.

[30] Arikunto, S. (2010). Evaluasi Program Pendidikan. Jakarta: PT. Bumi Aksara.

[31] Plomp, T., \& Nieveen, N. (2013). Educational Design Research. Netherlands: Enschede.

[32] Lampiselkä, J., Kaasinen, A., Kinnunen, P., \& Malmi, L. (2019). Didactic Focus Areas in Science Education Research. Education Sciences, 9(4): 294.

[33] Habig, B., Gupta, P., Levine, B., \& Adams, J. (2020). An informal science education program's impact on STEM major and STEM career outcomes. Research in Science Education, 50(3): 10511074.

[34] Mader, M. J. (2015). Impact of Participatory Teaching on Students' Generic Skills in Tertiary Education. African Educational Research Journal, 3(3): 190-197.

[35] Ural, E. (2016). The effect of guided-inquiry laboratory experiments on science education students' chemistry laboratory attitudes, anxiety and achievement. Journal of Education and Training Studies, 4(4): 217-227.

[36] Raviv, A., Cohen, S., \& Aflalo, E. (2019). How should students learn in the school science laboratory? The benefits of cooperative learning. Research in Science Education, 49(2): 331-345.

[37] Loveys, B. R., \& Riggs, K. M. (2019). Flipping the laboratory: improving student engagement and learning outcomes in second year science courses. International Journal of Science Education, 41(1): 64-79.

[38] Faisal, F., \& Martin, S. N. (2019). Science education in Indonesia: past, present, and future. AsiaPacific Science Education, 5(1): 1-29.

[39] Al-Gaseem, M., Bakkar, B., \& Al-Zoubi, S. (2020). Metacognitive thinking skills among talented science education students. Journal for the Education of Gifted Young Scientists, 8(2): 897-904. 